\title{
Reading Characters: Pedagogy of the Person and Victorian Shakespeare in Charlotte Brontë's Shirley
}

Kate Nesbit

In her still-influential lectures on Home Education (1886), British educator Charlotte Mason recommends cultivating children's literary taste through regular "Shakespeare evenings." On these special nights, families would partake in the "banquet that is Shakespeare" (6.246) by reciting and performing excerpts from the plays of England's most revered bard. During the nineteenth century, arguably the century of Shakespeare's "greatest revival" (Ziegler 205), Britons largely encountered Shakespeare through practices of reading and recitation in the home or schoolroom rather than through professional staged performances. Even so, professional theatre takes center stage in most academic work on Victorian Shakespeare, to the neglect of the small-time Shakespeare-the amateur community performances, the schoolroom readings, and "Shakespeare evenings"-popular in both Victorian entertainment and education. ${ }^{1}$ Shakespearean drama was a staple of nineteenth-century literacy trainingexcerpts from his plays fill the pages of the period's readers, reciters, and elocution manuals. However, the plays were a particularly valuable educational tool because they seemed to teach a greater lesson; while teaching students to read and speak, Shakespeare's plays also instructed readers in a form of interpersonal literacy. Through Shakespeare, students learned how to read human psychology and personality - to read, as Mason writes, "man on the lines of character" (4. 134). As a teacher of character, Shakespeare's plays served as a tool for facilitating self-discovery as well as for deciphering and understanding others.

This paper considers, more specifically, the appropriation of Shakespeare for the purpose of "teaching character" in a scene of Charlotte Brontë's second novel, Shirley (1849). In the sixth chapter of the novel, Brontë's heroine, Caroline Helstone, proposes that her cousin (and future husband), Robert Moore, read Coriolanus aloud. Her goal, or "moral tack," is to make Moore - a proud and 


\section{IJCS}

stubborn mill owner who is unsympathetic to the plight of his workers - see himself in the character of Coriolanus, the "proud patrician" who, like Moore, is "faulty as well as great" (Brontë 70). While the Coriolanus reading begins as simply an activity to fill the evening, the reading's purpose becomes increasingly pedagogical. First, Robert Moore, half-Belgian and a native French speaker, requests that Caroline listen and correct errors in his English pronunciation. In doing so, Robert requests that he and Caroline enact the quintessential scene of the Victorian schoolroom: that of the reading or reciting pupil corrected and evaluated by a listening pedagogue. Caroline, Moore suggests, is "to be the teacher," Moore the pupil, and "Shakespeare...our science" (68). Yet, as scholarship on Shirley often notes, Caroline actually offers a lesson not in English pronunciation, but in Englishness, as well as, the novel implies, "English" feeling and sympathy. "Glorious William," Caroline suggests in a metaphor akin to Coleridge's Aeolian harp, shall "pass a skillful hand" over the lyre of Moore's heart, making him feel his "virtues" and "vicious, perverse points" (67). Previous scholarship on this scene focuses on Caroline's attempt to "instruct Moore in the necessary qualities of leadership for an English capitalist employer" (Morris 109) and, as Nancy Armstrong has most famously argued, Anglicize and domesticate him through his consumption of the culture's moral values (224). ${ }^{2}$ In short, critics rightly observe, Shakespeare teaches Robert to be a better husband, mill owner, and Englishman.

By concentrating on Robert Moore's instruction, however, these scholars miss this scene's other reading lesson-Caroline's lesson rather than Robert's. This scene contains an example of what I've termed a "flipped pedagogy," in which the presumed reading instructor is actually herself learning to read. Caroline is not learning to read Shakespeare, but instead learning to read Robert Moore through Shakespeare, learning to read the "lines" of his character through his delivery of Coriolanus. Robert Moore is, after all, an inscrutable man; neither the novel's characters nor the novel's readers, in the words of Caroline's best friend Shirley Keeldar, "know what to think of him, whether to like him or not" (153). In the Coriolanus scene, the narration tracks Caroline's attempts - and the reader's attempts - to decipher mysterious Moore's character from his delivery. His emotional response to Coriolanus becomes Caroline's text to read. She identifies in Moore's face and voice evidence of his flaws; she watches him and witnesses, through his delivery, "a vicious point" in his personality or "another glimpse of brotherhood in error" (69). As he responds emotionally to the play, however, Caroline also marks his capacity for sympathy and feeling: "it was evident he appreciated the power, the truth of each portion." In this scene, Robert Moore learns to sympathize, but—just as crucially — Caroline also learns to read him as sympathetic. Shakespeare, the scene suggests, can both teach one how to feel and how to recognize another's feelings.

This capability also served as justification for including Shakespearean drama in curriculum on the art of reading and oral delivery: Shakespeare taught pupils of oratory how to discover emotions within themselves and make those emotions legible to an audience. Excerpts from Shakespeare's plays filled the 
pages of almost every elocution and recitation manual of the period - so much so that manuals published later in the century started to advertise their collections as offering "something new," omitting "the much-quoted Shakespeare" and other "hackneyed pieces" (Soper 2). One of the most famous elocutionists to incorporate Shakespeare into his manuals was the late eighteenth-century actor, philologist, and lexicographer John Walker. In the 1830s and 40s, Walker's books were still the definitive authorities on English pronunciation and oral delivery. Charlotte Brontë herself would have read his work in her copy of The Union Dictionary, a pronunciation dictionary compiled from the works of Walker, as well as Samuel Johnson and Joshua Steele.

In his textbook Elements of Elocution, Walker used Shakespeare's plays to provide what Paul C. Edwards describes as a "portrait gallery" (312) of the dramatic passions - codified expressions of emotions like joy, pity, terror, etc. For Walker, Shakespeare proved valuable because passages from Shakespeare's plays made readers express or exhibit bodily signs of emotions in predictable and legible ways. Walker thought that a given passage from a work of Shakespeare would present a passion in a manner convincing enough to propel students into that emotional state and - more importantly — enable these students to portray the appropriate physical signs. ${ }^{3}$ As Walker says of Suffolk's monologue in Act III, Scene II of Henry VI Part II: "who can read these admirable descriptions of anger without finding his whole frame braced, and his mind strongly tinctured with the passion delineated!" (284). Read Suffolk's monologue aloud, he suggests, and you will feel and look angry. Read York's soliloquy pitying Richard II in the play's final act, Walker claims, and you too will feel and legibly express "pity" (See Figure 1). You will find a "compassionate tenderness in your voice," exhibit a "feeling of pain in the countenance," and notice a "gentle raising and falling" of your hands and eyes (284). Bizarre as this might seem, Walker believed that this portrayal of pity would not be artificial, but rather a product of the "original feeling" (Walker 315) roused in the reader by the Richard II excerpt. The text of a Shakespeare soliloquy turns the reader's body into a legible text, translates internal emotions into external expression.

The Coriolanus scene in Shirley, then, builds on this theory; Caroline employs the play in part because she hopes the act of reading Shakespeare will make Robert - her potential husband - into a text she can read. The implied analogy here (the comparison of deciphering the character of one's lover with reading a book) crops up frequently in Shirley. The other romantic pair of this novel, the wealthy and headstrong Shirley Keeldar and her former tutor Louis Moore (Robert's brother), also figure each other as books to read, texts to decipher. Louis mentions to Shirley that his "character is not, perhaps, quite as legible... as a page of the last new novel might be" (357). Later, he describes his desire to access Shirley's undisclosed passions as a desire to "read a line in the page of her heart" (456). Like Caroline, Louis Moore sees character reading as courtship.

In a later scene, a scene clearly meant to parallel the "schoolroom" of Robert's Coriolanus reading, Louis Moore—like Caroline—also receives a kind 


\section{IJCS}

of flipped reading lesson, this time with Shirley as the text he learns to decipher. When Louis Moore and his lover (and former pupil), Shirley, discuss one of her former compositions, Shirley reflects: "I could never correct that composition...Y Your censor-pencil scored it with condemnatory lines, whose signification I strove vainly to fathom" (364). Louis responds, however, that his "lines" were not "indications of fault at all." These annotations, he implies, were instead moments in which he found her nature in her homework; he underlined sentences in which he found "Miss Keeldar, her mark, traced on every page." Here, Brontë puns: Shirley's French homework, her "composition," is actually the text of her character, her "composition." This discussion of Shirley's composition mirrors the Coriolanus reading, in which Robert Moore wishes Caroline's "whole attention to be fixed on [his] accent" (68). To ensure this, he insists she "follow the reading with her eyes - she must look at the book." As the scene reveals, however, the "book" at which she looks, the reading she follows with her eyes, is not Shakespeare's Coriolanus, but rather Robert and his character. She identifies not errors in his accent, but flaws and virtues in his "composition." In both reading lessons, the tutor - who seems to be identifying errors in language or accent-is actually learning to identify signs of character, the "marks" of a person they must learn to read before marriage.

Shirley's omniscient, schoolmistress-like narrator also attempts to read the novel's characters and to decipher the "texts" of characters' bodies using not Shakespeare, but phrenological analyses. Charlotte Brontë took great interest in phrenology, that popular Victorian practice that joins psychology and character reading by studying the shape and size of the cranium as an indication of character and mental abilities. Shirley includes numerous passages of what one critic calls "pure phrenological jargonese"as the narrator analyzes her story's characters through their deficits and surpluses in the organs of benevolence, ideality, wonder, and veneration (qtd. in Shuttleworth 57). Brontë, Sally Shuttleworth argues, took particular interest in phrenology because, unlike physiognomy, the science did not see external signs as directly expressive of an inner character quality (58). Instead, external signs - the shape of the head, more precisely — provided clues about the functioning of the brain. Taken individually, the shape of each cranial organ means nothing - only in interpreting the pattern or relationship of a person's head shape can you determine a person's propensities and potential (61). In short, phrenology served a function similar to that of the text of Coriolanus in Shirley: both served as tools for decoding the external signs of a person's complex interiority, for deciphering a character's propensities for vice and for virtue.

In the Victorian imagination, phrenology, like Shakespearean drama, promised to provide a map for identifying patterns in human psychology and personality. Nineteenth-century phrenologists, in fact, considered the works of Shakespeare the most convincing evidence in favor of their science. Phrenological periodicals used Shakespeare's characters to demonstrate the method and vocabulary for their character readings. Practitioners rewrote portions of Shakespeare in phrenological language, claiming that their theories of human psychology were parallel (Kurshnan 27). Phreno-mesmerists, who tried to 
stimulate various phrenological organs of mesmerized subjects, cited moments when mesmerized subjects recited Shakespeare upon the stimulation of specific organs as proof for phrenological science. One subject, for example, "gave the dagger scene in Macbeth in a most excellent style" when brain regions corresponding to "Language, Ideality, and Cautiousness were touched" (Jones 189). Similar testimonies abounded in early Victorian phrenological literature. The 1835 volume of the Phrenological Journal includes nine examples of "Shakespeare, quoted" by mesmerized subjects ("Index" 67). In all of these cases, phrenologists assume the "Shakespeare quoted" to be a manifestation of the mesmeric subject's interiority, as Caroline assumes Robert's reading of Coriolanus to be a manifestation of his true character and his otherwise inscrutable psychology.

In Brontë, as in phrenological literature, the act of reading people - be it through their head shapes or their Shakespeare delivery - is always a complex political act. As Shuttleworth argues, Brontë embraced phrenology, which we now associate with racism, eugenics, and xenophobia, because it promised to redraw the map of social hierarchy in order to create a vision of society in which vocation, status, and societal role are determined not by class, race, or gender, but rather by the brain's makeup. If a person has a large organ of ideality (the organ tied to imagination), then that person is a potential poet, regardless of gender, ethnicity, or station. Careful reading of character, Brontë suggests, makes legible unexpected alliances, strange kinships across boundaries of class and gender. Examples of character-reading in Shirley, for example, train readers to notice the cross-gender and cross-class doubles of the novel: two reserved and mysterious yet headstrong landlords - the woman, Shirley Keeldar, and the man, Robert Moore; two stubborn and vengeful antagonists - the mill owner, Robert Moore, and the mill worker, Joe Scott; and two wise, nature-loving, and imaginative poets - the working-class William Farren and William Shakespeare.

And yet, ironically, if there is one skill in which Shirley's narrator seems bent on teaching her audience, it is not how to make characters legible, but rather how to recognize characters as ultimately unknowable. Shirley's narrator is, as Carol Bock has observed, a narrator continually "struggling with an audience liable to make facile and inaccurate judgements" (119) - a narrator anticipating and correcting readers' inaccurate predictions, poking fun at readers' desires and hopes, and withholding information that would provide clarity or interpretive satisfaction. The novel's early reviewers complained of being "nagged, bullied" and "lectured endlessly" by this "deliberately humiliating" narrator determined to make her narrative as inscrutable as her mysterious protagonists (qtd. in Bock 109). Unlike Caroline in the Coriolanus scene, Shirley's narrator refuses to allude to her "moral tack" (Brontë 70). She teases her readers in the novel's closing sentences: "I think I now see the judicious reader putting on his spectacles to look for the moral. It would be an insult to his sagacity to offer directions. I only say, God speed him in the quest!" (482). One ends the novel reminded that the world and the people that populate it have "queer changes" (482), changes that even the most "judicious reader" cannot predict or explain. If, then, Brontë borrows a 


\section{IJCS}

lesson in reading character from Shakespeare's Coriolanus, a play featuring a "proud patrician" who is misunderstood by his people, it is that a person's character, like the character of Shakespeare's "proud patrician," will always be read inaccurately or incompletely. And yet she tempts her readers to try. God speed us in our quests!

Notes

${ }^{1}$ As Michael Dobson notes in book on Shakespeare and amateur performance, the capacious field of Shakespeare performance studies often neglects small-time Shakespeare as an object for critical inquiry. He identifies his book, Shakespeare and Amateur Performance: A Cultural History (2011) as the "first ever sustained examination" (1) of non-professional Shakespeare performance. Dobson devotes an entire chapter to the nineteenth century, focusing on the period's invention and embrace of "amateur dramatic societies," which would put on full-play productions. Georgianna Ziegler, in her work on women and Shakespeare in the nineteenth century, has also worked to remedy this neglect, as she discusses the period's domestic reading practices. Shakespeare performance and reading in the nineteenthcentury schoolroom and in home education, however, is a topic left underexplored.

${ }^{2}$ See similar arguments in Green, Lane, and Nyborg. Green sees Caroline as instructing Robert in a "romantic form of reading" that is "key to her revisionary feminist Christianity" (361). Lane argues that Caroline teaches Moore to recognize and overcome his misanthropy, Nyborg, to improve his professional service skills. All focus on what Robert Moore learns, however, and assume that Caroline has him read for his own edification only, not, as I argue, for her own.

${ }^{3}$ For more on Walker's use of Shakespeare, see Edwards.

\section{Works Cited}

Armstrong, Nancy. Desire and Domestic Fiction: A Political History of the Novel. Oxford UP, 1990.

Brontë, Charlotte. Shirley. 1849. Wordsworth Editions, 1993.

Dobson, Michael. Shakespeare and Amateur Performance: A Cultural History. Cambridge UP, 2011.

Edwards, Paul C. "Elocution and Shakespeare: An Episode in the History of Literary Taste." Shakespeare Quarterly, vol. 35, no. 3, 1884, pp. 305-14.

Greene, Sally. "Apocalypse When?: Shirley's Vision and the Politics of Reading." Studies in the Novel, vol. 26, no. 4, 1994, pp. 350-371.

Kurshan, Ilana. "Mind Reading: Literature in the Discourse of Early Victorian Phrenology and Mesmerism." Victorian Literary Mesmerism, edited by Martin Willis and Catherine Wynne, Editions Rodopi BV, 2006.

Lane, Christopher. "Charlotte Brontë on the Pleasure of Hating." ELH, vol. 69, no. 1, 2002, pp. 199-222. 
Mason, Charlotte. "Volume 4: Ourselves." Ambleside Online's Annotated Charlotte Mason Series. Stone Table Productions, 2003. Web. 15 December 2014. $<\mathrm{http}: / / \mathrm{ww}$.amblesideonline.org/CM/CM4Ourselves.epub/>.

---. "Volume 6: Towards a Philosophy of Education." Ambleside Online's Annotated Charlotte Mason Series. Stone Table Productions, 2003.Web.15 December 2014. $<$ http://www.amblesideonline.org/CM/CM6PhilosophyofEducation.epub/>

Morris, Pam. "Heroes and Hero-Worship in Charlotte Brontë's Shirley." NineteenthCentury Literature, vol. 54, no. 3, 1999, pp. 285-307.

Nyborg, Erin. "Captains of Industry and the Subversion of the Professional Ideal in Charlotte Brontë's The Professor and Shirley.” Brontë Studies, vol. 40, no. 4, 2015, pp. 306-313.

The Phrenological Journal and Miscellany, vol. 9, September 1834-March 1836.

R. Jones, "Interesting Experiments in Cheshire," Phreno-Magnet, July 1843, p. 189.

Shuttleworth, Sally. Charlotte Brontë and Victorian Psychology. Cambridge UP, 1996.

Sillars, Stuart. Shakespeare and the Victorians. Oxford UP, 2013.

Soper, Henry. Soper's Scrapbook Series: A Miscellaneous Collection of Prose and Poetry for Recitation and Reading, Designed for Schools, Home, and Literary Circles. 1880. Kessinger Publishing, 2010.

Walker, John. Elements of Elocution. London, 1781.

Ziegler, Georgianna. "Women and Shakespeare." Shakespeare in the Nineteenth Century. Edited by Gail Marshall, Cambridge UP, 2012, pp. 205-228. 